\title{
cDNA Cloning of Biologically Active Chicken Interleukin-18
}

\author{
KIRSTEN SCHNEIDER, ${ }^{1, *}$ FLORIAN PUEHLER, ${ }^{1, *}$ DANIELA BAEUERLE, ${ }^{1}$ SANDRA ELVERS, ${ }^{1}$ \\ PETER STAEHELI, ${ }^{1}$ BERND KASPERS,${ }^{2}$ and KIRSTEN C. WEINING ${ }^{1}$
}

\begin{abstract}
By searching a chicken EST database, we identified a cDNA clone that appeared to contain the entire open reading frame (ORF) of chicken interleukin-18 (ChIL-18). The encoded protein consists of 198 amino acids and exhibits approximately $30 \%$ sequence identity to IL-18 of humans and various others mammals. Sequence comparisons reveals a putative caspase- 1 cleavage site at aspartic acid 29 of the primary translation product, indicating that mature ChIL-18 might consist of 169 amino acids. Bacterially expressed ChIL-18 in which the $\mathrm{N}$-terminal 29 amino acids of the putative precursor molecule were replaced by a histidine tag induced the synthesis of interferon- $\gamma($ IFN- $\gamma)$ in cultured primary chicken spleen cells, indicating that the recombinant protein is biologically active.
\end{abstract}

\section{INTRODUCTION}

I NTERLEUKIN-18 (IL-18) WAS ORIGINALLY DESCRIBED as an interferon- $\gamma($ IFN- $\gamma$ )-inducing factor and was cloned from Propionibacteriumacnes-treated mouse livers in 1995.(1) In the ensuring years, IL-18 has been characterized in great detail, as summarized in some recent reviews. ${ }^{(2-4)} \mathrm{IL}-18$ belongs to the IL-1 family of cytokines. Like IL- $1 \beta$, it is synthesized as a precursor molecule that lacks a typical signal peptide and is cleaved by caspase- 1 into a bioactive cytokine. ${ }^{(5,6)}$ Computer modeling studies predict that IL-18 contains many $\beta$-sheets, as does IL$1 \beta .^{(7)} \mathrm{IL}-18$ binds to a heterodimeric receptor complex in which both the binding and the signaling chain are members of the IL-1 receptor family. ${ }^{(8,9)}$ The signaling cascades of IL-18 and IL- $1 \beta$ are identical, and both lead to activation of NF- $\kappa$ B. ${ }^{(10,11)}$

The biologic properties of mammalian IL-18 are complex. ${ }^{(4)}$ It shares properties with IL-12, as both cytokines can induce Th1 immune responses. ${ }^{(4,10)}$ The observed synergistic effects of IL-18 and IL-12 on IFN- $\gamma$ induction seem to result from IL18 receptor upregulation by IL-12(12) and a concerted activation of the IFN- $\gamma$ promoter. $^{(13)}$ Other functions ascribed to IL18 include induction of IL- $1 \beta$, tumor necrosis factor- $\alpha$ (TNF- $\alpha$ ), and several chemokines, ${ }^{(14)}$ as well as enhancement of natural killer (NK) cell cytotoxicity. ${ }^{(15)}$ An important role for IL-18 has been shown in several models of infectious, inflammatory, and autoimmune diseases, as well as in tumor models. ${ }^{(4)}$ IL-18 mRNA and precursor synthesis is constitutive, ${ }^{(16)}$ indicating that IL-18 activity is regulated at the level of cytokine precursor processing and secretion. The in vivo activity of IL-18 is further regulated by a secreted IL-18-binding protein. ${ }^{(17,18)}$ Interestingly, several poxviruses also encode soluble factors that bind and neutralize IL-18, thereby interfering with the host defense system. ${ }^{(19,20)}$

It has been unclear to date whether birds have a cytokine with structural and functional properties of mammalian IL-18. Here, we report the identification of a cDNA encoding a chicken homolog of IL-18 (ChIL-18). We further show that bacterially expressed ChIL-18 is a potent inducer of IFN- $\gamma$ in primary chicken spleen cells.

\section{MATERIALS AND METHODS}

\section{Cell culture}

HD-11 cells ${ }^{(21)}$ were grown in Dulbecco's modified essential medium (DMEM) supplemented with $8 \%$ fetal bovine serum (FBS) and $2 \%$ chicken serum. Chicken spleen cells were prepared as described ${ }^{(22)}$ and maintained in RPMI 1640 medium supplemented with $8 \% \mathrm{FBS}$ and $2 \%$ chicken serum at $40^{\circ} \mathrm{C}$ in a $\mathrm{CO}_{2}$ incubator.

\section{cDNA cloning}

Analysis of BLAST search results of a chicken bursal EST database (http://genetics.hpi.uni-hamburg.de/dt40.html) indicated that clone dkfz426 3m9r1 contained sequence informa-

\footnotetext{
${ }^{1}$ Abteilung Virologie, Institut für Medizinische Mikrobiologie und Hygiene, University of Freiburg, 79008 Freiburg, Germany.

${ }^{2}$ Institut für Tierphysiologie, University of Munich, 80539 Munich, Germany.

*These two authors contributed equally to this work.
} 


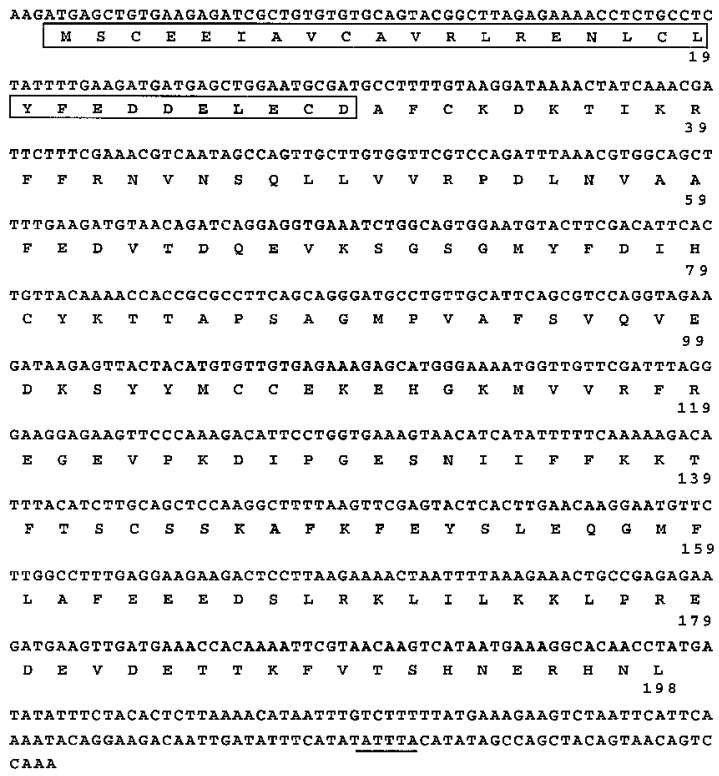

60

FIG. 1. cDNA sequence (EMBL/GenBank accession No. AJ277865) and predicted amino acid sequence of ChIL-18. Nucleotide numbering is at right. An ATTTA sequence motif in the 3 '-noncoding region, which presumably mediates mRNA instability, is underlined. The protein sequence is given in the single letter code. Amino acid numbers are indicated below the sequence. The propeptide that is probably cleaved off by caspase- 1 after the conserved aspartate residue at position 29 is boxed.

tion for ChIL-18. To isolate a cDNA fragment containing the complete open reading frame (ORF) for this protein, PCR was performed with primers 5'-CCCAAGCTTATGAGCTGTGAAGAGATCGCTGTG- ${ }^{\prime}$ ' and 5' ${ }^{\prime}$-TGCTCTAGATCATAGGTTGTGCCTTTCATTATG-3 ', which introduced HindIII and $\mathrm{XbaI}$ restriction sites near the ends of the amplification product. cDNA from HD-11 cells stimulated for $5 \mathrm{~h}$ with $5 \mu \mathrm{g} / \mathrm{ml}$ lipopolysaccharide (LPS) ${ }^{(23)}$ was used as template. The PCR product was directionally cloned between the HindIII and the $\mathrm{XbaI}$ restriction sites of vector pcDNA3 (Invitrogen, Groningen, Netherlands).

\section{Purification of histidine-tagged ChIL-18 from Escherichia coli}

A fragment of ChIL-18 cDNA (nucleotide positions 91-600 in Fig. 1) was amplified by PCR using primers 5'-CGCGGATCCGCCTTTTGTAAGGATAAAACT-3 ' ${ }^{\prime}$ and 5'-CCCAAGCTTTCATAGGTTGTGCCT-3 ', which introduced unique BamHI and HindIII restriction sites near the ends of the fragment, and the PCR product was cloned between the BamHI and HindIII restriction sites of prokaryotic expression vector $\mathrm{pQE9}$ (Qiagen, Chatsworth, CA). Expression of this construct in $E$. coli strain M15 yielded His-ChIL-18, which corresponds to putative mature ChIL-18 with an N-terminal extension consisting of the peptide Met-Arg-Gly-Ser-(His)6-Gly-Ser. His-ChIL-18 was purified by affinity chromatography on a nickel chelate agarose column. Purification conditions were as described for ChIFN- $\gamma^{(24)}$ with slight modifications. Induction was done at $\mathrm{OD}_{600}=0.8$ for a period of $3 \mathrm{~h}$ using an isopropylthiogalactose (IPTG) concentration of $0.5 \mathrm{mM}$. We checked for purity of recombinant His-ChIL-18 by standard SDS-PAGE (15\% gel) and subsequent Coomassie blue staining.

\section{Induction of IFN- $\gamma$ synthesis by His-ChIL-18 in chicken spleen cells}

Chicken spleen cells were prepared as described, ${ }^{(22)}$ seeded at a density of $2.5 \times 10^{5}$ cells per well of a 96-well plate, and incubated with the indicated amounts of recombinant His-ChIL-18, His-ChIL-18 that has been heat-inactivated for $10 \mathrm{~min}$ at $100^{\circ} \mathrm{C}$, or the control protein His-MxA. At $48 \mathrm{~h}$ after onset of cytokine treatment, cell supernatants were assayed for the presence of biologically active IFN- $\gamma$. For this purpose, HD-11 cells were incubated for $24 \mathrm{~h}$ with samples of the various supernatants. Activation of HD-11 cells by IFN- $\gamma$ was measured as a function of nitrite accumulation in the culture supernatants using the Griess assay. ${ }^{(25,26)}$ To confirm that the observed nitric oxide (NO) production was induced by IFN- $\gamma$, supernatants of spleen cells stimulated with the indicated amounts of His-ChIL-18 were preincubated for $2 \mathrm{~h}$ at $37^{\circ} \mathrm{C}$ with a polyclonal neutralizing antiserum to ChIFN- $\gamma^{(24)}$ at a dilution of 1:200 and subsequently transfered to HD-11 cells.

Chicken MSCEE----IAVCAVRLRENLCLYF---EDDELECDAFCKDKTIKRFFRNVNSQLLVVRPDLNVAAFEDVTDQE-VKSGSGMYFDIHCYKTTAPSAGMPVAFSVQ 97

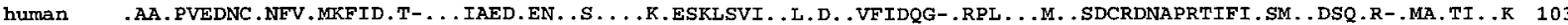
mouse .AAMSED.SCVNFKEMMFID.T- . . IPE.NGD. . S.N.GRL.HCTTAVI. I.D.V.F.DKR-OP-V. . M. . IDQSA.EPQTRLI.YM. DSEVR-.LA.TL..K 101 rat .AAMSEEGSCVNEKEMMFID.T-... IPEDNGD..S.H.GRLHCTTAVI.SI.D.V.F.DKR-.PPV...MP.IDRTANE.QTRLI.YM..DSEVR-.LA.TL..K 103 porcine .AA.P-EDNC.SEVEMRFIN.T- ...VAEN.ED. .S.Y.GKLEPKLSII. . .D.V.FINQG-HQ.V. . MP.SDCSDNAPQTV.I.YM..DSLTR-.LA.TI . . 102 equine .AAGPVEDNC.SLVEMKFID.T-_..VAEN.EN. .S.Y.GRLEPKLSII. .L.D.V.FINQG-.QPV...MP.SDCTDNAPQTV.I.YM..DSLTR-.LA.TI..K 103 bovine .AA.QVEDYC.SFVEMKFIN.T- ..VAEN.ED..S.H.GKLEPKLSII..L.D.V.FINQG-.QPV...MP.SDCSDNAPQTI.I.YM..DSLTR-.LA.TI... 103

FIG. 2. Comparison of IL-18 sequences from chicken and various mammals. Alignments were done using the Jotun Hein method. ${ }^{(27)}$ Dots represent identical amino acids, and alignment gaps are indicated by hyphens. The arrow marks the position of a conserved aspartate residue at which caspase-1-mediated cleavage of the precursor molecules is predicted to occur. 


\section{RESULTS AND DISCUSSION}

\section{Cloning of ChIL-18 cDNA}

By analyzing the BLAST search results of a chicken EST database, we identified clone dkfz4263m9r1, which seemed to encode a polypeptide with significant similarity to mammalian IL-18. PCR with cDNA from LPS-induced chicken HD-11 cells and primers corresponding to the EST clone resulted in the amplification of a cDNA fragment whose nucleotide sequence (EMBL/GenBank accession No. AJ277865) precisely matched the sequence of the original EST clone. This cDNA codes for a polypeptide of 198 amino acids (Fig. 1).

Alignment of ChIL-18 with IL-18 from various mammals revealed amino acid identities of approximately $30 \%$. A comparison of chicken and mammalian IL-18 sequences is shown in Figure 2. IL-18 is synthesized as an inactive precursor in mammals that is activated by caspase- 1 , which cleaves the molecule after a conserved aspartate (arrow in Fig. 2). Sequence comparisons revealed that the critical aspartate residue is conserved in the ChIL-18 sequence (Fig. 2), indicating that it may also be cleaved at this residue. Mature ChIL-18 thus seems to consist of 169 amino acids.

\section{Recombinant His-ChIL-18 from E. coli is biologically active}

Assuming that pro-ChIL-18 is cleaved after the conserved aspartate residue at position 29 (Fig. 2), we used PCR to amplify a cDNA fragment that encodes an N-terminally truncated form of ChIL-18. After cloning into the prokaryotic expression vector $\mathrm{pQE9}$, the resulting construct should yield a translation product that consists of an $\mathrm{N}$-terminal histidine tag followed by the putative mature ChIL-18 sequence. This product, which we designated His-ChIL-18, was purified from E. coli by affinity chromatography on nickel chelate agarose beads. After elution under nondenaturing conditions, peak column fractions were pooled and diluted to a concentration of $0.5 \mathrm{mg}$ protein per $\mathrm{ml}$. His-ChIL-18 appeared as a prominent band on SDS-PAGE at about $23 \mathrm{kDa}$. It was more than $50 \%$ pure (Fig. $3 \mathrm{~A}$ ).

To determine whether bacterially expressed recombinant His-ChIL-18 is biologically active, we tested its ability to induce IFN- $\gamma$ synthesis in cultured primary chicken spleen cells. Spleen cells were incubated with various concentrations of purified His-ChIL-18 or as negative controls with either heat-inactivated His-ChIL-18 or an unrelated protein (His-MxA). At $48 \mathrm{~h}$ after onset of treatment, the spleen cell supernatants were analyzed for the presence of IFN- $\gamma$ by a standard bioassay that monitors IFN- $\gamma$ activity as a function of NO secretion by the chicken macrophage cell line HD-11.(28) As shown in Figure $3 \mathrm{~B}$, only supernatants of spleen cells treated with nondenatured recombinant ChIL-18 exerted macrophage-activating activity. The minimal concentration of His-ChIL-18 that induced significant amounts of IFN- $\gamma$ in spleen cells was $60 \mathrm{ng} / \mathrm{ml}$. Treatment of spleen cells with $250 \mathrm{ng} / \mathrm{ml}$ of either His-MxA or heatinactivated His-ChIL-18 did not cause significant secretion of NO. In addition, neither the His-ChIL-18 nor the His-MxA preparation induced NO synthesis when added directly to HD11 indicator cells at concentrations as high as $1 \mu \mathrm{g} / \mathrm{ml}$ (data not shown), indicating that the observed effect was a specific activity of ChIL-18.
Treatment of supernatants from His-ChIL-18-treated chicken spleen cells with a polyclonal antiserum that neutralizes ChIFN$\gamma^{(24)}$ blocked their NO synthesis-inducing activity (Fig. 3B), demonstrating that the factor secreted by spleen cells after treatment with ChIL-18 is indeed IFN- $\gamma$.

Our discovery that chickens have a cytokine with structural and functional similarities to mammalian IL-18 further supports the view that most parts of the cytokine network had already been in place when the avian and mammalian lineages separated about 300 million years ago. In this context, it is of in-

\section{A}

\section{$\mathrm{kDa}$}

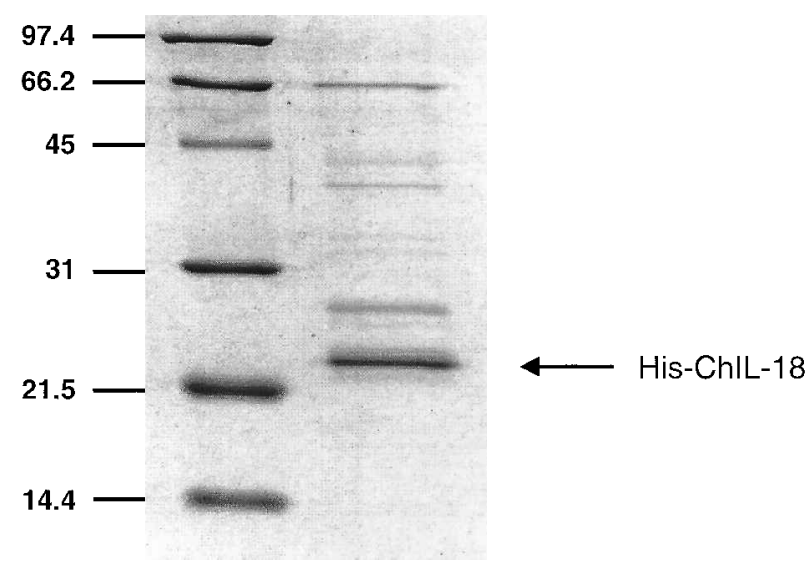

B

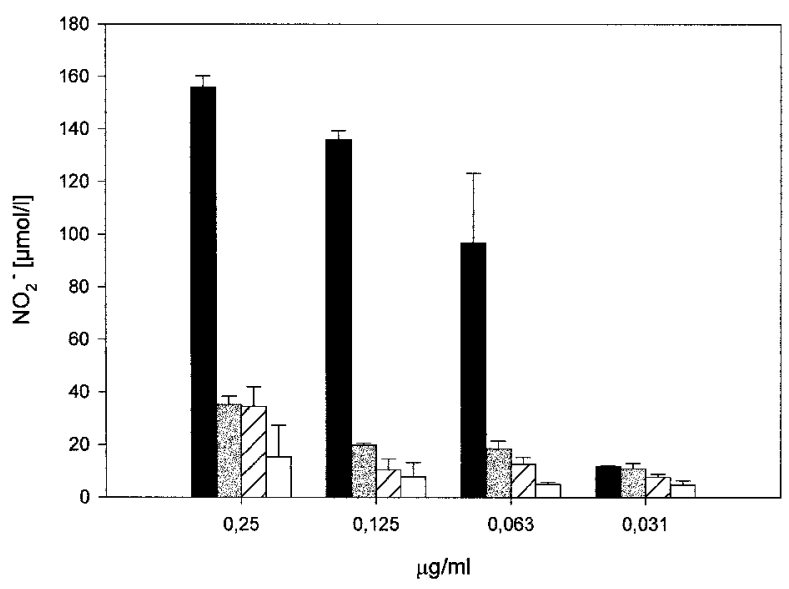

His-Chll-18

Pre. His-ChlL-18 + anti-ChIFN$\measuredangle \triangle$ His-ChlL-18 $\left(100 \mathrm{C}^{\circ}\right)$ $\square$ His-MXA

FIG. 3. Purified His-ChIL-18 from E. coli is biologically active. (A) Coomassie blue-stained gel showing a sample of purified His-ChIL-18. The molecular sizes of marker proteins are indicated. (B) Chicken spleen cells were treated for $48 \mathrm{~h}$ with the indicated concentrations of either active His-ChIL-18, heatinactivated His-ChIL-18, or the control protein His-MxA Spleen cell supernatants were added to HD-11 cells either directly or after preincubation with a polyclonal antiserum that neutralizes ChIFN- $\gamma$ in order to monitor IFN- $\gamma$-induced NO secretion. 
terest to note that the various chicken cytokines for which cDNA have to date been cloned (type I IFN, ${ }^{(29,30)} \operatorname{IFN}-\gamma,{ }^{(24,31)}$ IL- $1 \beta,{ }^{(23)}$ IL-2, ${ }^{(32)}$ IL-18 [this report]) are all considered to drive Th1 immune responses. Such cytokines as IL-4, IL-5, or IL-10, which characterize Th2 immune responses, have to date not been found in the chicken. It is unclear at present whether the latter cytokines are absent from birds or were simply missed because of the lack of appropriate assay systems.

In summary, the unlimited availability of biologically active recombinant ChIL-18 now makes it possible to test if this cytokine has the potential to modulate vaccine-induced immune responses in chickens.

\section{ACKNOWLEDGMENTS}

This work was supported by grants from the Deutsche Forschungsgemeinschaft and from Intervet Int. B.V., Boxmeer, Holland.

\section{REFERENCES}

1. OKAMURA, H., TSUTSUI, H., KOMATSU, T., YUTSUDO, M., HAKURA, A., TANIMOTO, T., TORIGOE, K., OKURA, T., NUKADA, Y., HATTORI, K., AKITA, K., NAMBA, M., TANABE, F., KONISHI, K., FUKUDA, S., and KURIMOTO, M. (1995). Cloning of a new cytokine that induces IFN- $\gamma$ production by T cells. Nature 378, 88-91.

2. AKIRA, S. (2000). The role of IL-18 in innate immunity. Curr. Opin. Immunol. 12, 59-63.

3. DINARELLO, C.A., NOVICK, D., PUREN, A.J., FANTUZZI, G., SHAPIRO, L., MÜHL, H., YOON, D.-Y., REZNIKOV, L.L., KIM, S.-H., and RUBINSTEIN, M. (1998). Overview of interleukin-18: more than an interferon- $\gamma$ inducing factor. J. Leukocyte Biol. 63, 658-664.

4. DINARELLO, C.A. (1999). IL-18: a Th1-inducing, proinflammatory cytokine and new member of the IL-1 family. J. Allergy Clin. Immunol. 103, 11-24.

5. GU, Y., KUIDA, K., TSUTSUI, H., KU, G., HSIAO, K., FLEMING, M.A., HAYASHI, N., HIGASHINO, K., OKAMURA, H., NAKANISHI, K., KURIMOTO, M., TANIMOTO, T., FLAVELL, R.A., SATO, V., HARDING, M.W., LIVINGSTON, D.J., and SU, M.S.-S. (1997). Activation of interferon- $\gamma$ inducing factor mediated by interleukin- $1 \beta$ converting enzyme. Science $\mathbf{2 7 5}, 206-209$.

6. GHAYUR, T., BANERJEE, S., HUGUNIN, M., BUTLER, D., HERZOG, L., CARTER, A., QUINTAL, L., SEKUT, L., TALANIAN, R., PASKIND, M., WONG, W., KAMEN, R., TRACEY, D., and ALLEN, H. (1997). Caspase-1 processes IFN$\gamma$-inducing factor and regulates LPS-induced IFN- $\gamma$ production. Nature 386, 619-623.

7. BAZAN, J.F., TIMANS, J.C., and KASTELEIN, R.A. (1996). A newly defined interleukin-1? Nature 379, 591 .

8. TORIGOE, K., USHIO, S., OKURA, T., KOBAYASHI, S., TANIAI, M., KUNIKATE, T., MURAKAMI, T., SANOU, O., KOJIMA, H., FUJI, M., OTHA, T., IKEDA, M., IKEGAMI, H., and KURIMOTO, M. (1997). Purification and characterization of the human interleukin-18 receptor. J. Biol. Chem. 272, 2573725742

9. BORN, T.L., THOMASSEN, E., BIRD, T.A., and SIMS, J.E. (1998). Cloning of a novel receptor subunit, AcPL, required for interleukin-18 signalling. J. Biol. Chem. 273, 29445-29450.

10. ROBINSON, D., SHIBUYA, K., MUI, A., ZONIN, F., MURPHY,
E., SANA, T., HARTLEY, S.B., MENON, S., KASTELEIN, R., BAZAN, F., and O'GARRA, A. (1997). IGIF does not drive Th1 development but synergizes with IL-12 for IFN- $\gamma$ production and activates IRAK and NF- $\kappa$ B. Immunity 7, 571-581.

11. ADACHI, O., KAWAI, T., TAKEDA, K., MATSUMOTO, M., TSUTSUI, H., SAKAGAMI, M., NAKANISHI, K., and AKIRA, S. (1998). Targeted disruption of the MyD88 gene results in loss of IL-1- and IL-18-mediated function. Immunity 9, 143-150.

12. AHN, H.-J., MARUO, S., TOMURA, M., MU, J., HAMAOKA, T., NAKANISHI, K., CLARK, S., KURIMOTO, M., OKAMURA, H., and FUJIWARA, H. (1997). A mechanism underlying synergy between IL-12 and IFN- $\gamma$-inducing factor in enhanced production of IFN- $\gamma$. J. Immunol. 159, 2125-2131.

13. BARBULESCU, K., BECKER, C., SCHLAAK, J.F., SCHMITT, E., MEYER ZUM BÜSCHENFELDE, K.-H., and NEURATH, M.F. (1998). IL-12 and IL-18 differentially regulate the transcriptional activity of the human IFN- $\gamma$ promoter in primary $\mathrm{CD}^{+} \mathrm{T}$ lymphocytes. J. Immunol. 160, 3642-3647.

14. PUREN, A.J., FANTUZZI, G., GU, Y., SU, M.S.-S., and DINARELLO, C.A. (1998). Interleukin-18 (IFN- $\gamma$-inducing factor) induces IL- $1 \beta$ and IL- 8 via TNF- $\alpha$ production from non$\mathrm{CD}_{1}{ }^{+}$human blood mononuclear cells. J. Clin. Invest. 101, 711-721.

15. HYODO, Y., MATSUI, K., HAYASHI, N., TSUTSUI, H., KASHIWAMURA, S., YAMAUCHI, H., HIROISHI, K., TAKEDA, K., TAGAWA, Y., IWAKURA, Y., KAYAGAKI, N., KURIMOTO, M., OKAMURA, H., HADA, T., YAGITA, H., AKIRA, S., NAKANISHI, K., and HIGASHINO, K. (1999). IL18 upregulates perforin-mediated NK activity without increasing perforin messenger RNA expression by binding to constitutively expressed IL-18 receptor. J. Immunol. 162, 1662-1668.

16. PUREN, A.J., FANTUZZI, G., and DINARELLO, C.A. (1999). Gene expression, synthesis, and secretion of interleukin- 18 and interleukin-1beta are differentially regulated in human blood mononuclear cells and mouse spleen cells. Proc. Natl. Acad. Sci. USA 96, 2256-2261.

17. NOVICK, D., KIM, S.-H., FANTUZZI, G., REZNIKOV, L.L., DINARELLO, C., and RUBINSTEIN, M. (1999). Interleukin-18 binding protein: a novel modulator of the Th1 cytokine response. Immunity 10, 127-136.

18. AIZAWA, Y., AKITA, K., TANIAI, M., TORIGOE, K., MORI, T., NISHIDA, Y., USHIO, S., NUKADA, Y., TANIMOTO, T., IKEGAMI, H., IKEDA, M., and KURIMOTO, M. (1999). Cloning and expression of interleukin-18 binding protein. FEBS Lett. 445, 338-342.

19. XIANG, Y., and MOSS, B. (1999). IL-18 binding and inhibition of interferon- $\gamma$ induction by human poxvirus-encoded proteins. Proc. Natl. Acad. Sci. USA 96, 11537-11542.

20. SMITH, V.P., BRYANT, N.A., and ALCAMI, A. (2000). Ectromelia, vaccinia and cowpox viruses encode secreted interleukin18-binding proteins. J. Gen. Virol. 81, 1223-1230.

21. BEUG, H., VON KIRCHBACH, A., DOEDERLEIN, G., CONSCIENCE, J.-F., and GRAF, T. (1979). Chicken hematopoietic cells transformed by seven strains of defective avian leukemia viruses display three distinct phenotypes of differentiation. Cell $\mathbf{1 8}$, 375-390.

22. MARTIN, A., LILLEHOJ, H.S., KASPERS, B., and BACON, L.D. (1993). Antigen-specific T cell proliferation following coccidia infection. Poult. Sci. 72, 2084-2094.

23. WEINING, K.C., SICK, C., KASPERS, B., and STAEHELI, P. (1998). A chicken homolog of mammalian interleukin-1beta: cDNA cloning and purification of active recombinant protein. Eur. J. Biochem. 258, 994-1000.

24. WEINING, K.C., SCHULTZ, U., MÜNSTER, U., KASPERS, B., and STAEHELI, P. (1996). Biological properties of recombinant chicken interferon-gamma. Eur. J. Immunol. 26, 2440-2447. 
25. DING, A.H., NATHAN, C.F., and STUEHR, D.J. (1988). Release of reactive nitrogen intermediates and reactive oxygen intermediates from mouse peritoneal macrophages. Comparison of activating cytokines and evidence for independent production. J. Immunol. 141, 2407-2412.

26. STUEHR, D.J., and NATHAN, C.F. (1989). Nitric oxide. A macrophage product responsible for cytostasis and respiratory inhibition in tumor target cells. J. Exp. Med. 169, 1543-1555.

27. HEIN, J. (1990). Unified approach to alignment and phylogenies. Methods Enzymol. 183, 626-645.

28. PUEHLER, F., WEINING, K.C., SYMONS, J.A., SMITH, G.L., and STAEHELI, P. (1998). Vaccinia virus-encoded cytokine receptor binds and neutralizes chicken interferon-gamma. Virology 248, 231-240.

29. SEKELLICK, M.J., FERRANDINO, A.F., HOPKINS, D.A., and MARCUS, P.I. (1994). Chicken interferon gene: cloning, expression, and analysis. J. Interferon Res. 14, 71-79.

30. SICK, C., SCHULTZ, U., and STAEHELI, P. (1996). A family of genes coding for two serologically distinct chicken interferons. J. Biol. Chem. 271, 7635-7639.
31. DIGBY, M.R., and LOWENTHAL, J.W. (1995). Cloning and expression of the chicken interferon-gamma gene. J. Interferon $\mathrm{Cy}$ tokine Res. 15, 939-945.

32. SUNDICK, R.S., and GILL-DIXON, C. (1997). A cloned chicken lymphokine homologous to both mammalian IL-2 and IL-15. J. Immunol. 159, 720-725.

Address reprint requests to: Dr. Peter Staeheli Department of Virology University of Freiburg

Hermann-Herder-Strasse 11 D-79008 Freiburg, Germany

Tel: +49-761-203-6579

Fax: +49-761-203-6562 E-mail: staeheli@ukl.uni-freiburg.de

Received 18 May 2000/Accepted 13 June 2000 